\title{
Proliferating Cell Nuclear Antigen
}

National Cancer Institute

\section{Source}

National Cancer Institute. Proliferating Cell Nuclear Antigen. NCI Thesaurus. Code

C17323.

Proliferating cell nuclear antigen (261 aa, $29 \mathrm{kDa}$ ) is encoded by the human PCNA gene.

This protein is involved in the regulation of both DNA replication and DNA mismatch repair. 